\title{
Educational Governance in Turkey: From the view of New Public Management and New Social Movement Theories $^{1}$
}

\author{
Yeni Kamu Yönetimi ve Yeni Sosyal Hareketler Teorileri Perspektifinden \\ Türkiye'de Eğitim Yönetişimi \\ Ceray ALDEMİ*
}

\begin{abstract}
New Public Management (NPM) and New Social Movement (NSM) theories emerged as a response to sociopolitical conditions of the 1980s. In order to understand the socio-political and socio-economic transformations in Turkey, it is necessary to focus on NPM and NSM literature together. More importantly, in the age of NPM and NSM it is vital to understand the development process of education, and its importance as a tool which has been used to create social capital in Turkey, since this paper aims to answer the following questions: How is it possible to explain increasing religiosity in education in secular Turkey? How does NPM open up opportunity spaces in the governance of education? How have NSMs become involved in the resourcing of education? How have NSMs redefined educational governance? This paper will attempt to show the importance of education for all governments from the beginning of the Turkish Republic, the Turkish governments used education as a tool for spreading their political ideology. So there have been various implementations from secularist policies to Islamist militarist policies in the Turkish education system. After giving some information about educational policies, which have been shaped around secularism, militarism and Islamism, the second section will show the interaction between education and New Public Management (NPM). By doing a primary and secondary literature review, this paper will first discuss the neoliberal changes that happened between the 1980s and 2000s, and secondly, will indicate how NPM agendas transformed education from a social service to the private service.
\end{abstract}

Key Words: Educational Governance, NPM, Religious Groups, Social Movements, NSM

$\ddot{O} \mathbf{z}$

Yeni Kamu İşletmeciliği (NPM) ve Yeni Toplumsal Hareket (NSM) teorileri 1980'lerin sosyo-politik koşullarına tepki olarak ortaya çıktı. Türkiye'de de dönemin sosyo-politik ve sosyo-ekonomik dönüşümleri anlamak için, NPM ve NSM literatürlerine birlikte odaklanmak gerekmektedir. Daha da önemlisi, yeni toplumsal hareketlerin yeni kamu işletmeciliğine entegre olmaya başladığı bir dönemde, eğitimin gelişim sürecini ve önemini, Türkiye'de sosyal sermaye yaratmak için kullanılan bir araç olarak anlamak hayati önem taşımaktadır; bu sebeple bu çalışma aşağıdaki soruları yanıtlamayı amaçlamaktadır: Seküler Türkiye'de eğitimde artan dindarlığı açıklamak mümkün müdür? Yeni Kamu İşletmeciliği ile birlikte, eğitim yönetişimininde firsat alanları açılmış mıdır? Yeni Sosyal Hareketler eğitim finansmanına nasıl dâhil olurlar? NSM'ler eğitim yönetişimini nasıl yeniden tanımladı? Bu makale, Türkiye Cumhuriyeti'nin kuruluşundan bu yana eğitimin tüm hükümetler için önemini göstermeye çalışacak ve eğitimin iktidarların ideolojilerini yaygınlaştırmak için bir araç olarak kullandığına değinecektir. Çalışmada, birincil ve ikincil kaynaklar üzerinden bir literatür incelemesi yapılarak ilk olarak 1980'ler ve 2000'ler arasındaki eğitimde gerçekleșen neoliberal dönüşüme ve bu dönüşümde etkili olan NPM ve NSM teorilerine değinilecektir. Çalışma eğitim ile Yeni Kamu İşletmeciliği ve Yeni Toplumsal Hareketler arasındaki etkileşimi gösterecektir.

Anahtar Kelimeler: Eğitim Yönetişimi, Yeni Kamu Yönetimi, Dini Gruplar, Toplumsal Hareketler, Yeni Toplumsal Hareketler

\section{Introduction}

New Public Management (NPM) portrays the transformation in the way in which public services were planned and controlled. In many countries, the transformation from the 'Old Bureaucratic' type of management overlaps with the rise of the 'New Right' ideology in the 1980s. For this reason, NPM is often defined as an ideological shift not only in Western, but also in Turkish literature. However, the scholarship showed that even some new left administrations such as Australia and New Zealand adopted the NPM reforms. Therefore, the

\footnotetext{
${ }^{1}$ This paper is based on a part of a thesis submitted by the author to The University of Manchester for the degree of Doctor of Philosophy in the Faculty of Humanities, 2014.

* Dr.Öğr.Üy., Muğla Sitkı Koçman Üniversitesi, İktisadi ve İdari Bilimler Fakültesi Kamu Yönetimi Bölümü, cerayaldemir@mu.edu.tr.
}

Aldemir, C., (2018). Educational Governance in Turkey: From the view of New Public Management and New Social Movement Theories, Gaziantep University Journal of Social Sciences, 17 (2), 438-452, Submission Date: 22-12-2018, Acceptance Date: 28-03-2018.

Araştırma Makalesi. 
countries in which NPM reforms had been applied indicated that the reforms were practical reactions to the socio-economic situations of the 1980s, such as a global economic depression, dissatisfaction with public service, increasing taxes and the liberalization of both state and society.

The main characteristics of NPM, which were repeated in the literature by many academics can be summarized as follows: the decentralisation of the public services, the rising usage of private sector management techniques into the public sector, the increasing involvement of the private sector, the third parties and non-governmental organizations such as civil society organizations, and social movements in the public sector. In other words, this can be described as building governance in the public sector. Whether one is convinced that NPM is a pragmatic answer to contemporary needs or an ideological response to the $1980 \mathrm{~s}$, the emergence of NPM indicates the relationship between the state institutions and the nongovernmental organizations. In other words, NPM created an environment for the nongovernmental sectors to deliver public services by paying attention to people's expectations. The literature underlines that it is only possible to understand the application of NPM by considering any given country's socio-political and economic background.

Likewise, NPM, New Social Movement (NSM) emerged as a response to socio-political conditions of the 1980s. As the NSM literature pointed out, by the late 1990s the social movements shifted from targeting the state to targeting everyday life. These 'new' movements did not focus on the economy and institutional politics, but rather they built up civil society. Although there are different theories and several definitions of NSM in the literature, the most repeated ones showed that the focus of the movements has become the creation of identity. Della Porta and Diani (1999) give us a concluding definition of social movement: informal networks based on shared beliefs and solidarity, which mobilize about contradictory issues through the frequent use of various forms of protest.

As we have learnt from Melluci (1996), the power of movements is assured questions that have to do with boundaries and consciousness, rather than the reform or appropriation of institutions: "Who are we? What are our goals and means?" According to the scholarly literature, the social movements are struggles around the institutional potentials of cultural patterns of a given social type. In other words, social conflicts must be understood in cultural and normative terms; social movements are normatively oriented interactions between adversaries with conflicting interpretations and opposed societal models of a shared cultural field (Cohen and Arato, 1995).

After this brief summary of NPM and NSM literature, it is vital to underline why the issue of bringing together the state and non-state actors, or namely, governance, has come into consideration in a number of related fields of different social science disciplines, attracting scholars from different backgrounds, such as sociology, political science, and public administration (Bevir and Rhodes, 2003). Although both NPM and 'governance', and NSM and 'social movements' have been analysed and debated in the academy, the above review of literature indicated that they both suffer from a one-sided view of the transformation process, which is approached in some texts by way of descriptive or perspective overview (Barry et.al, 2006). For instance, while Hood (1999) mentioned the "managerial reform movement" when discussing change in the public sector, he did not explore the derivation of 'movement' from within the social movement literature (in Barry et.al, 2006, p.439).

Overall, the literature on NPM and NSM demonstrate several weaknesses. First of all, the review showed us that in order to understand wider considerations of transformation in Public Administration; it is useful to take intellectual inspiration from social movement scholarship. Both sets of literature have theoretical and terminological convergence on issues 
such as identity, governance, liberalization, transparency and participation. So, in order to be aware of this interpenetration it is vital to read NPM and NSM theories together. However, only a limited number of scholars mentioned this necessity, such as Barry, Berg and Chadler (2006, 2007) and Newman (2001) -a way of analysing engagement through 'opportunity spaces'.

In other words, in order to understand the socio-political and socio-economic transformations in Turkey, it is necessary to focus on NPM and NSM literature together. More importantly, in the age of NPM and NSM it is vital to understand the development process of education, and its importance as a tool which has been used to create social capital in Turkey, since this paper aims to answer the following questions: How is it possible to explain increasing religiosity in education in secular Turkey? How does NPM open up opportunity spaces in the governance of education? How have NSMs become involved in the resourcing of education? How have NSMs redefined educational governance? This paper will attempt to show the importance of education for all governments from the beginning of the Turkish Republic, the Turkish governments used education as a tool for spreading their political ideology. So there have been various implementations from secularist policies to Islamist militarist policies in the Turkish education system. After giving some information about educational policies, which have been shaped around secularism, militarism and Islamism, the second section will show the interaction between education and New Public Management (NPM).

This paper will first discuss the neoliberal changes that happened between the 1980s and 2000s, and secondly, will indicate how NPM agendas transformed education from a social service to the private service. More specifically it will look at the changing rules, using secondary and primary documentary sources, in order to find the answer of the abovementioned research question about NPM and education policies. Finally, in the third section, by underlining the importance of education and showing that it is not a coincidence that education has gradually become the main area of interest for the some religious movements (RMs), the researcher analyses the emergence of new social movements, and explains how NPM opens up opportunity spaces that RMs fill in the governance of education.

\section{Neoliberal Changes and Education Reform in Turkey}

Education International, which represents organizations of teachers and other education employees across the globe, defines public education as "a system open to all without discrimination on the basis of gender, religion, culture or social class, free of charge, publicly funded, and managed and evaluated in accordance with the objectives and principles established democratically by public authorities" (Leeuwen in Ball and Youdell, 2007, p.3). As we understand from this definition, education is not a commodity and should not be privatized. However, at both the international and national level, there is a great tendency towards the commercialization or privatization of education, which is illustrated by the New Right governments, as the only way of modernization and reform in education (Apple, 2006).

As summarized above, as a public service is defined by constitution, education has faced several reforms in Turkey, such as restructuring, privatization, and decentralization. Similar to many countries, the trend towards the privatization of public education is hidden. It is masked by the language of "educational reform", or introduced silently as "modernization" (Keskin, 2003). For instance, although from the beginning of the Republic to the 1980s there were limited numbers of private initiatives in the field of education, after the 1980s by these educational reforms the number of private entrepreneurs has dramatically increased in Turkey. In other words, by the 1980s the government transferred its duties gradually to the private sector. This has caused weakening conditions in public education in terms of the quality of schools, classes, and teachers. 
According to Gök (2003, p.102), the application of neoliberal policies in the country affected families' income levels in a negative way. However, in order to deal with the poor quality of education in the public schools, families usually preferred private schools. As Ozdalga (1995, p.421) has indicated, the achievements of the public and private sectors are highly different from each other in Turkey. Since families thought the government reforms on education have not worked, wealthy families found their own way, and by choosing private schools, have spent a huge amount of money on their children's education.

The weakening conditions of public education mostly affected the low income group, and the public schools have become education ghettos, where on average, there were twentysix students per teacher in public schools, while the equivalent figure for private schools was seven students per teacher (see Table 1). This situation increased the discrimination between the high and low-income groups. In other words, the increasing number of private schools and quality differences between public and private education institutes caused a bipartition of education.

Table 1: The Number of Public and Private Schools in 2016

\begin{tabular}{|l|c|c|c|c|}
\hline $\begin{array}{l}\text { Type of } \\
\text { schools }\end{array}$ & $\begin{array}{l}\text { Number of } \\
\text { schools }\end{array}$ & $\begin{array}{l}\text { Number of } \\
\text { students }\end{array}$ & $\begin{array}{l}\text { Number of } \\
\text { teachers }\end{array}$ & $\begin{array}{l}\text { Number of students } \\
\text { per teacher }\end{array}$ \\
\hline $\begin{array}{l}\text { Public Secondary } \\
\text { Education }\end{array}$ & 8457 & 3.780 .552 & 280.471 & 13,4 \\
\hline $\begin{array}{l}\text { Private Secondary } \\
\text { Education }\end{array}$ & 2618 & 514.480 & 52.569 & 9 \\
\hline
\end{tabular}

Source 1: http://sgb.meb.gov.tr/meb_iys_dosyalar/2017_09/08151328_meb_istatistikleri_orgun_egitim_2016_2017.pdf

Aksoy (2011) defined this process as commercialization, or the involvement of the private sector in education in Turkey. In the Turkish case, both mean the involvement of the private sector in the delivery of education. Accordingly, during this period some forms of commercialization and privatization tendencies were introduced explicitly into the public education system under the labels "educational reform" or "modernization". Though methods commercialization or privatization of education are varied and complex, Murphy (1996) defines ten types of privatization strategies; load shedding, asset sale, self-help, user fee, contracting, franchising, voucher, grants/subsidies, deregulation and volunteerism. Furthermore, Ball and Youdell (2007) say that most of the privatizations are being done using hidden methods. They add that there are two types of privatization; endogenous and exogenous.

Endogenous privatization means privatization in public education; in order to make the public sector more like businesses, and more business-like, it involves the importing of ideas, techniques and practices from the private sector. Exogenous privatization means privatization of public education and involves not only the opening up of public education services to private sector participation on a for-profit basis, but also uses the private sector to design, manage or deliver aspects of public education (Ball and Youdell, 2007:13). Although the first type is well established and widespread around the world, in Turkey the second one has started to grow and become more common too.

Without examining the country's socio-political and economic conditions, Turkish governments supported both the endogenous and exogenous privatizations by grants and subsidies. By being given free land and buildings, the private entrepreneurs were encouraged to invest in the education sector. Doubtless, the privatization tendencies trace back to the 24th January Decisions, which underlined the necessity of reducing public expenditure by privatizing the public services. From the late 1980s, the privatization of education was begun 
implicitly by the "Build Your Own School" campaign. Since 1990 this process had been controlled systematically by global actors such as the IMF and the World Bank (WB). For instance, the Ministry of National Education (MEB) signed a protocol with the WB, which emphasized the reconstruction of primary and secondary education by localization policies (MEB, 2001).

Again, in 1998 as a part of Structural Adjustment Programs (SAPs), the Turkish Education System was reconsidered by the suggestion of the European Commission, and the education sector was formulated under the guidance of SAPs, which offered liberalization and privatization of education in Turkey. By signing the General Agreement on Trade on Services (GATS), Turkey also accepted the marketization of education in the country, and opened up the national education systems to Foreign Service providers. Also the 7th-Five Year Development Plan suggested 'the paid education model' for secondary schools. There are several similar applications in Turkey which caused firstly, passive privatizations by collecting several fees under different names in public schools, and secondly, active privatizations by encouraging both families and private sectors to prefer/open private schools. In addition to those interventions, which were related to the financing of education, there were some others, which encouraged the localization of education in Turkey. Hence, neoliberal policies suggest decentralization, which decreases the role of central government. With the Public Management Basic Law Draft (PMBLD), the government attempted to establish a market-oriented public administration, in which the education services are controlled by the local authorities. In this model the central government, MEB, only have the right of controlling unified education when preparing the curriculum.

Additionally, during the last 30 years, the private schools were supported in different ways. For instance, as the Minister of Finance, Simsek proposed that in order to both increase the attendance at private schools and reduce the state's responsibility to education services, the government is willing to pay some of the tuition fees (Munyar, 9th April, 2012). Simply, it seems that by sharing its education tasks, the government wants to decrease its expenses on education. However, according to Serim $\left(17^{\text {th }}\right.$ April, 2012), this project aims to transpose the state money to the private sector, and especially to the religious movements, which run significant numbers of private schools. Briefly, during the last thirty years the idea of privatized education has been actualised, and this spread the inequality among students. While highincome groups increased their education monopolies, the low-income groups lost their futures, which could be created by a good quality education (Sayilan, 2007).

Doubtless, the main reason behind these transformations was the changes in the idea of public services, in which NPM has been the key mechanism in the political reform and cultural re-engineering of the public sectors (Ball and Youdell, 2007, p.19) and the NPM movement opens up opportunity spaces that NSMs especially the RMs fill in the governance of education. Various types of NSMs have emerged in Turkey, and are increasing their demands in the public sphere. Among the NSMs in Turkey the most influential ones are the ISMs. According to Yavuz (2008, p.29), by obtaining opportunity spaces in the public sphere, some terms related to modernity, such as democratization, modernization, and economic expansion have been made acceptable in society by these movements. Therefore, it is possible to say that although there are more than ninety-thousand NGOs and NSMs in Turkey, the RMs are playing a vital role in the shaping of society (Aksit, in Uysal, 2009, p.168).

Gellner (1994) has emphasized that because of the following three reasons it is not possible to discuss civil society movements or social movements in Muslim societies. Firstly, Islam resists secularism, which is a sine qua non for social movements. The puritan and radical wings of Islam not only perceived the grassroots of Islam or Sufism as a main reason for underdevelopment, but also rejected them without questioning. According to Gellner (1994), in 
Muslim societies, Islam, like nationalism, resists modernization in Western societies, and rather than secularizing and retiring to the private sphere, insists on being visible in the public sphere. This leads us to the second reason: the authoritative Islamist leaning in the public sphere is an obstacle for the autonomous social movements' formation. Finally, the third reason is the extensiveness of tribes in Muslim societies.

After explaining the impracticability of social movements in Muslim societies, Gellner (1994, p.199-200) underlines that Turkey is highly different from other Muslim societies, as the military and political elites of the country were imposing a pluralist social movement to the civil people. As Aksit (in Uysal, 2009) indicated that the authoritarian, centralist- state culture paradoxically creates the ideal conditions for the social movements in Turkey. Aksit promotes his idea with Laclau's thesis, and adds that collective identities and movements rapidly emerge in such an environment (Ibid.) The RMs, which challenge the secularist discourses of the state, could be an example of this rapid emergence. The movements' numbers increase in this situation.

Since the 1980s the Islamic Social Movements have been creating new collective identities as a result of the neoliberalization of the country's socio-political and economic policies. On the one hand, Yavuz (in Wiktorowicz, 2004) explained this process by using the term "creation of opportunity spaces", which includes mass media and private educational facilities by which religious values and ways of life had been created and circulated (Ibid, p.270). On the other hand, according to Tekeli (in Simsek, 2004), RMs emerged in a "new urban cultural group", which occurs at the intersection of the traditional rural culture and urbanized/industrialized segments of society. In brief, as we can see from Beris' (2008) findings, the movements started their activities in the 1980s or early 1990s at a time when the Turkish economy and society had entered a remarkable socio-economic transformation process.

In such an environment, by way of the created opportunity spaces, the newly emerged urban cultural group found a way to increase their voices. Therefore, RMs are "specialized in creating political space for incomings, marginal populations, abandoned programs and inaudible complaints" (Yavuz, 2003, p.24) that were discounted by the Kemalist Secularist state. Thus, RMs represent a 'coming out' of private Muslim identity in the public spaces, or in Gole's (2000) words, they made the religion more visible in the public sphere. For this reason, since the opportunity spaces or the RMs enabled the creation of a new socio-political awareness, they should not been accepted that as aiming to control the state, but rather they seek the reconstruction of everyday life by transforming personal identity (Yavuz, 2003, p.25). This new identity would be different from the existing one, which is based on secularism and antireligious discourses.

Of course, it is not easy to transform the mentioned everyday life which lies on following socio-political aspects of Kemalism. First of all, because of the Kemalist modernization ideology it is not possible to provide an inclusive social contract that comprises all cultural diversity. Secondly, since Kemalism was accepted as the most ideal ideology for a society, the political elites have never tolerated any other lifestyle. Therefore, through social engineering the Kemalist elites created a society by protecting Kemalist purity. However, according to Aktay (1997, p.282), ironically "the more democracy grows, the more religious resurgence is likely to increase". In this environment, by directly conflicting with the Kemalist project and its states structures, the RMs seek to mobilize and globalize their movements. To do this, the movements used neoliberal economy policies. However, during the early republic "Islam was not only relegated to the private sphere, but was also used as a national asset, a force to glue the nation together." (Turam, 2004, p.64). Following the neoliberal economic policies of Özal, it has a new role: "to resist the totalitarian and homogenizing policies of the Kemalist State" (Yavuz, 2000, p.28) and to transform not only everyday-life, but also the state's service tools, 
such as media and education. In brief, the changing socio-political and economic conditions of Turkey, such as democratization and market-economy rules, increased the role of RMs in society.

Although in Turkey the RMs emerged in the same environment, and are the results of a transformation in society, it is possible to speak of different types of RMs in terms of their orientation and methods of action. As it can be seen from Table 2, while the vertical statecentric movements are aiming to control the state and shape policies, the horizontal societycentric movements are not only seeking to transform the society by using the media and communication networks, but also viewing Islam as a cultural capital (Ibid, p.30). Additionally, while the vertical state-centric movements aim at top-down changes, the horizontal societycentric movements aim at bottom-up transformations in society.

Table 2: Typology of RMs and the Position of Turkish Movements

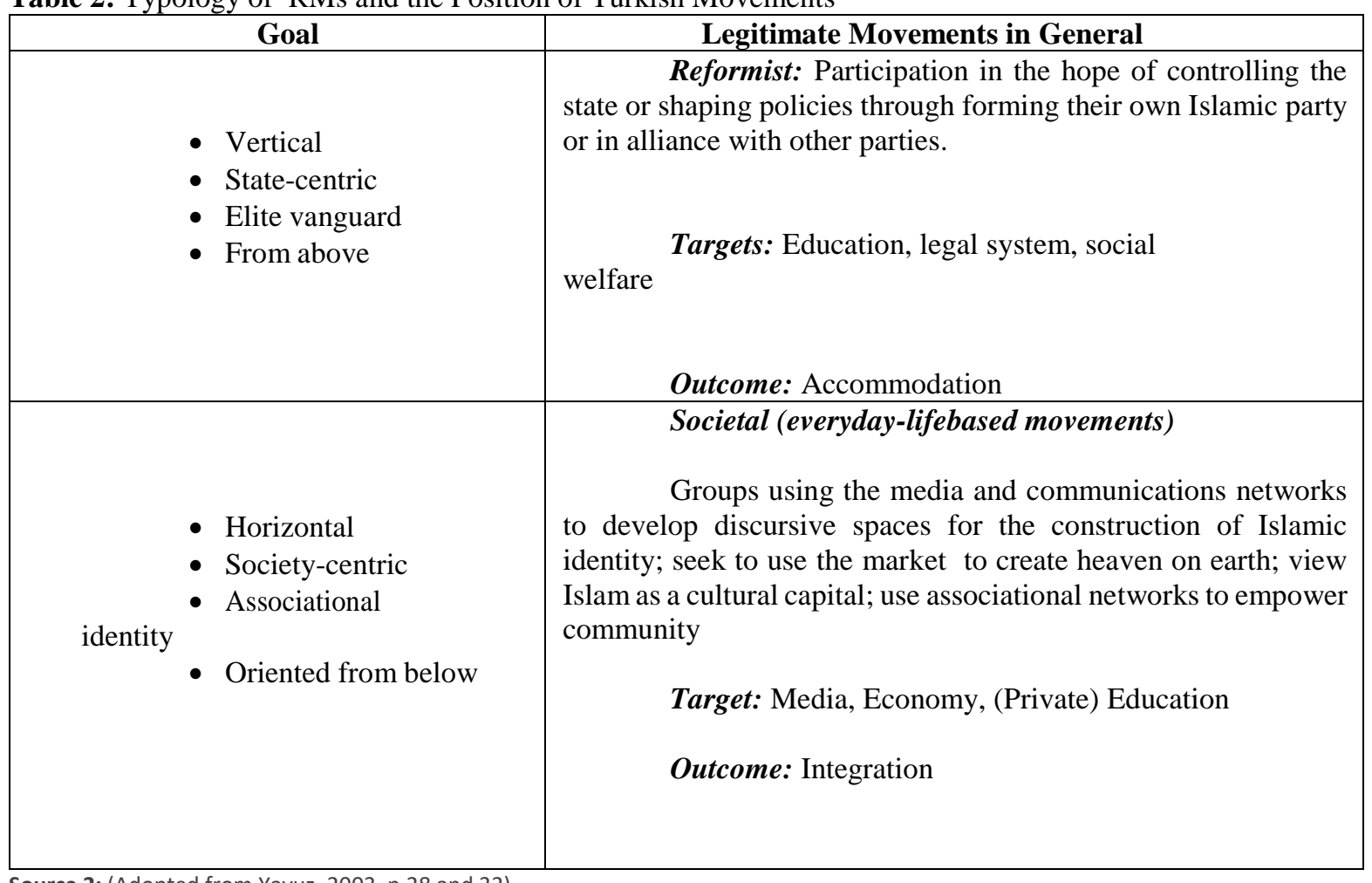

Source 2: (Adopted from Yavuz, 2003, p.28 and 32)

Currently, there are some widely recognized and largest religious movements in Turkey. They have become involved in politics by either forming or allying with the political parties. Furthermore, in order to build discursive spaces for the construction of Islamic identity, they established several media institutions, business and associational networks, and private education institutions, which will be analysed in the following section. Essentially, since there has been a sympathy to the movements from the political leaders coming from the central left (Ecevit), or the central right (Özal and Demirel), their commitment to the separation of religion and politics has not seemed incompatible with their tolerance for the RMs' pragmatic agendas in business and education (Turam, 2004).

\section{New Public Management and Education}

As mentioned above, NPM is characterized by marketization, privatization, managerialism, performance measurement, and accountability (Tolofari, 2005). Although these key terms are always mentioned with private sector and business principles, during the last few decades, the application of these principles in the administration of education is noticeable in education. Since education is a big business, and educators themselves constitute nearly one 
third of the public sector, in Turkey the governments have underlined the necessity of downsizing in public service during the last few decades (Boratav, 1995). Therefore, privatization and marketization, or applying business principles in the public sector, has been thought of as a method of this economizing (Tolofari, 2005).

For these reasons, especially, creating an education sector which is compatible with the market and its rules would mean a great downsizing in public services. According to the OECD (2010), the successful enforcement of these business principles, namely NPM, will make it possible for the state to offer a stable economy and increase both national and international investments. PMBLD (Public Management Basic Law Draft), which was an output of this discourse, took NPM into consideration. Through the draft law, the concept of "public management' entered into Turkish PA law texts. While until 2002 the term 'public administration' had been used, in order to be compatible with the NPM concept, 'public management' would be the 'new' term (Beris and Dicle, 2004).

In other words, the real application of NPM in Turkey was only possible with the PMBLD; with this draft law, the philosophy of NPM has been spread into public services and, according to Keskin (2003), there is no exception for the education services. Both the PMBLD and NPM are compatible with each other during the transformation of the education services. PMBLD proposes several reforms for the education services, and combines those reforms with the five year development plans, i.e. the 8th Five Year Development Plan emphasizes the importance of NPM for Turkish Public Services, and the government's aim to transform education service. Of course, there are economic, political, social, intellectual and technological drivers behind the application of NPM, namely PMBLD, in the education sector in Turkey. First of all, as mentioned earlier, the main reason for demanding a downsizing in public services is Turkey was dealing with public debts, fiscal problems and high degrees of inflation and unemployment (Boratav, 1995). Also, the country has critical shortages and has encountered bottlenecks in public finance. For instance, while in 1980 the state revenues were almost equal, from the 1990s there was a considerable difference between the revenues. Thus, public expenditures were accepted as a burden on public finance (see Figure 1). Therefore, the government found a public reform necessary and decided to reduce the government's role in the public sector (Yasamis, 2003, p.94).

Figure 1: Public Revenues and Expenditures in Turkey between 1980 and 2001

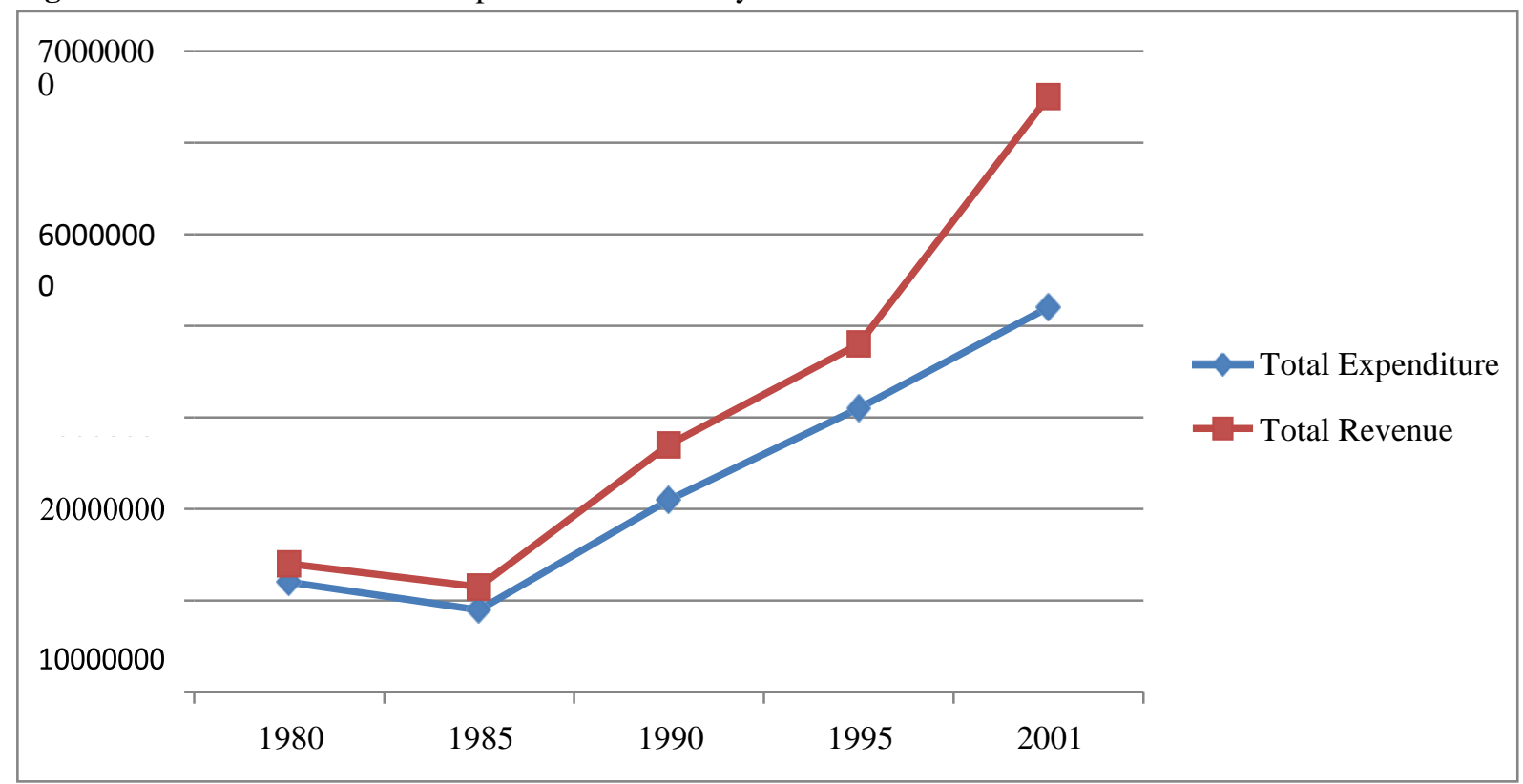

Source: Adapted from Yasamis (2003, p.94) 
In addition to the abovementioned economic drivers, the political drivers of public administration reform and acceptance of NPM were no different from other countries. Hence, Turkey has experienced a political liberalization from the 1980s, and has moved away from state-centric policies; the application of New Right ideologies accelerated when the governments and the governments' solutions were examined by society. The solution from the neoliberal thinkers was that market mechanisms and privatization could bring discipline, efficiency, and effectiveness to the public sector (Ferlie et al, 1996). Thus, in such a political environment, NPM was proposed as a solution for the Public Administration problems, or in the words of Hood's well-known article, (1991) "A Public Management for all Seasons".

In the case of Turkey, one can say that social factors were the propellant of the public administration reforms. According to TESEV (2001), bribery has become a wide-scale social, administrative, and political problem in Turkey. For this reason there are greater demands for accountability, efficiency, and effectiveness from the citizens. In addition, there is demand for modernization from the government. The reform showed its impact on the education sector too. The changes in the Public Administration literature could be accepted as the intellectual drivers of the Public Administration reform in Turkey. Since the Western literature has a huge impact on Turkish literature, scholars with reformist orientation responded to political demands for better management. Changes in technology were also drivers of public administration reform.

As a result of the abovementioned drivers, the agents of New Right ideology and NPM in Turkey suggested that the central government's role in schools should be reduced, and, therefore, business values began to be applied in all education systems. First of all, the main aim of the draft law was the liberalization of the general structure of public administration. PMBLD points out that although the previous reforms aimed to take NPM principles into account, they only managed to create economic liberalization. Therefore, it is vital to build a sustainable liberalization in public services. As mentioned in PMBLD, there are two main drivers for these changes; firstly, the competitive structure of the private sector - which is defined as the private sector's reason for success, and secondly, the improvements of civil society and social movements. When the developments of these two were considered together with the abovementioned intellectual, social and technological drivers, the government again polished the idea of privatization and decentralization. In this regard, in order to be a 'reactive administration', it has been suggested by the KYTKY that the public sector must be interactive with the social movements and market.

In this regard, how the adoption of NPM and the implementation of the PMBLD were intended to change the existing rules could be summarized in the three following key points. The first point is the restructuring of the education management. Even though the roles of central government in education service delivery were defined by the constitution, by restructuring education management, the PMBLD (article 7) delegated some of the central government's duties to the local government (Special Provincial Administrations, SPAs). Thus, the central government would only be responsible for the determination and improvement of the curriculum; teachers and schools would be controlled by the SPAs. This does not simply change the status of the teachers and schools, but also the features of the education service as a public service.

The second point is that the decentralization of education would interrupt the law on unification of education, which made uniform education a legal obligation. Since the law on unification of education had attracted several criticisms, such as lack of competition, diversity, and alternative schools, with PMBLD the government aimed to change these by introducing localization. Under PMBLD, since the central government (i.e. the Ministry of National Education (MEB)) is not allowed to establish local authorities, those changes have to be done by the local governments and the regional authorities that will finance education by inventing 
their own methods. According to Keskin (2003), these will not increase the competition, diversity, or alternative schools, but rather, will leave education to the different social movements or interest groups.

The third point is the privatization of education, or in other words, the establishment of profitable education managerialism. The PMBLD says that when public services are delivered by the private sector, they will be more effective, efficient, and economic than state-delivered services. For this reason, both the central government and the local governments have delegated their duties to the civil societies, non- governmental organizations, and social movements. In effect, these three points indicate that the PMBLD has changed the rules of education service delivery, and created opportunity spaces for the social movements.

Before NPM education was a pure public good, which is not normally provided at all by the private sector because they would be unable to make a profit. All educators and teachers were public employees, and there was a standard 'product' available in the education system. After NPM the neoliberal business ethos entered into the education sector. This ethos, promoting competition, efficiency, choice, and accountability not only controlled education, but also sought to redefine education from one of public good to that of private good. (Tolofari, 2005, p.84).

In Turkey, like in other developing states, NPM was applied as a top-down transformation (Sozen and Shaw, 2002), and it has the same objectives and mechanisms: (1) establishing managerialism, (2) developing explicit standards of performance, and (3) institutionalizing localization and decentralization in public education. These aims have caused many structural changes in the country. First of all, by establishing managerialism the roles and relationships changed, and this increased the involvement of local authorities and stakeholders in schools' decision making processes. Secondly, through performativity, schools and teachers were forced to make improvement plans, and this caused inequality among equals. Essentially, as a result of NPM in education, the structure of schools had been changed (Keskin, 2003).

Thirdly, the World Bank proposes the localization of education as a key tool of NPM, and it defines localization as "the transfer of authority and responsibility for public functions from the central government to intermediate and local governments or quasi-independent government organizations and/or the private sector" (World Bank, Decentralization). As is clear from this definition, this decentralization, or localization, is the prior condition for the adjustment of the education services to the market conditions. Although there are many criticisms of the application of these neoliberal policies and NPM tools to education services in Turkey (Keskin, 2003), the WB indicates that Turkey is later to apply managerialisation and decentralization when compared to other OECD member states. By the 8th Five Year Development Plan, Turkey gave a response to the WB, and showed how it was willing to apply NPM ethos to education services.

First of all, the application of total quality management (TQM) and curriculum laboratory schools (CLSs) were examples of the government's steps in this direction. By introducing such terms quality circles, governance, and internal and external customer, the government extended NPM in the education sector (Yildirim, 2002). Furthermore, the plan also highlights that in addition to the increase in the role of the private sector in education, the role of social movements and local governments should be increased by applying NPM and governance culture (DPT, 2000). Essentially, to decrease the role of central government or increase the private sector and local governments' roles in the education sector mean that the schools will have to find their own resources, which gives a significant role to the social movements, and gives NGOs an important role in the creation of social capital. 


\section{New Social Movements and Education in Turkey}

As we summarized above, the challenge between RMs and the secular state over social and political spaces in modern Turkish history demonstrates a unique conflict. However, this conflict turned into a power struggle after the 1980s, with the emergence of neoliberal, socioeconomic processes in Turkey. Both the economic and social conditions have intensified this conflict in the era of neoliberalism and new public management, and Islamic social movements have realized their power in the public sphere, especially in the education sector. In Turkey, the RMs are the most important Social Movements in the liberalization period. These movements have benefitted from the market economy and privatized education.

Since the religious movements realized the importance of education during the construction process of Islamic conscious, they have started to open private education institutions since the 1980s. Therefore, as Yavuz (2003, p.121) has underlined, "the struggle between state and society is focused on achieving influence in the educational sphere, which naturally is seen as central to shaping the future of the country". On the issue of the secularIslamist challenge it is possible to understand why state elites, or in other words, Kemalist elites, viewed the spread of these religious schools as a threat to both their social and political values.

As explained at the beginning of this chapter, education and public schools have been seen as the most important tool of social capital. Although the Kemalist state and its bureaucrats believed that in order to structure a new secularist Turkey, applying the secularist ethos into education is enough, the latest trends in education indicate that that is not enough. Additionally, rather than creating a uniform Turkish citizen, the system made differences more visible. The impact of the decreasing state role in public services and the private schools run by the ISMs increased year by year.

The Turkish state lost its control over the production of a state-centric secular identity after the opening of private, religiously-oriented high schools (Yavuz, 2003, p. 122). According to Turam (2011, p.83), although the state and the Islamic Movements had negotiated their own spheres clearly, this saved neither the Islamic actors nor the secular ones from tension and conflict. Furthermore, this tension and conflict between the two increased when the secularists defined themselves as the owners of both the public sphere and civil society.

When Muharrem İnce, who is an MP from the Republican People's Party (Turkish: Cumhuriyet Halk Partisi, CHP), the main opposition party, was asked what he means by civil society, he replied by referencing the CHP's political report on civil societies: "Civil society is a wide sphere of social organization and relations that stands between private life and state. The free individual is at the core of civil society. Civil society consists of social unions formed by free individuals with their free will" (Field Interview, 20/02/2011). When it has been asked if the Islamic Social Movements could be defined as civil society organizations, he clearly replied that "they are not, and being a non-governmental organization does not give them the right to be a civil society organization". He continued to say that their involvement in the public sector, by opening and running schools, is not acceptable; however, in Turkey, by using loopholes they managed to open private schools (Field Interview, 20/02/2011).

Ince claimed the involvement of the RMs in education was a threat, and underlined that the ISMs should stay in the private sphere rather than being visible in the public sphere, in public sectors such as health and education (Field Interview, 20/02/2011), Turam (2007, p.64) highlighted that this kind of recompilation of private/public has put pressure on the movements and created tension in the lives of insiders. Conversely, Turam points out that these kinds of tensions have assisted not only the RMs in acclimatising to the secular institutional setting, by enabling integration into the Republic, but also the secular state in adopting Islamic actors and learning to accommodate Islamic ways of life (Ibid.). In brief, one should not ignore the 
importance of these rearrangements and should understand that this is neither Islamisation of the state nor the state's support of Islam; in other words, this is neither a Muslim transformation and a secular pressure, nor a secular transformation and a Muslim pressure. This is a redefinition of the boundaries between RMs and the Kemalist secularist state, or the increasing involvement of the ISMs in education in the age of NSM.

\section{Conclusion}

The late 1980s have borne witness to several changes in Turkey. While the application of neoliberal policies in the economy and politics was changing the rules of public administration and public services, the increasing involvement of the social movements in the public sphere has made some of these movements more visible. However, this was either an unintended consequence of the NPM, or an unpredictable result of democracy. In Aktay's (1997, p.282) words "the more democracy grows the more religious resurgence is likely to increase". This environment has disturbed the Kemalist secularist elites. Hence, they define themselves as the owners of the Republic and the protector of Ataturk's revolutions. The spread of the ISMs within the public, and especially in education, has been seen as a threat to the future of the country.

The abovementioned Turkish education history indicates to us that there have been several reforms within education which were seen as a social capital creation tool. Therefore, in order to increase the development of the country, the governments brought about several reforms. Although the education sector and the level of literacy has developed, educational problems are much more multifaceted nowadays, since there are other issues in addition to secularism - Islamism's point of view, for instance the changing tendencies in the public administration which brought the private sector ethos to the agenda, made the Islamic conservative citizens of Turkey more demanding from both the government and public sector.

The emerging neoliberal changes in education are one of these tendencies. However, in Turkey, while education is defined as a public service and citizenship right, the trends towards privatization of public education is masked by the language of educational reform or modernization (Keskin, 2003). The increasing number of private schools also indicates the increasing number of private initiatives in the education sector. While, in many countries the rising involvement of the private sector in education, or in other words, the application of the NPM doctrines to education service delivery, increased the quality of education because of the competitive environment, in Turkey the private sector involvement weakened the conditions of public education. This situation directly affected the low-income group, and public schools become education ghettos. The ghettoized public schools made the private schools and private education more attractive in families' eyes. Also, by having a large amount of money from the state, such as İncentive credit, and exemption from income tax, the private schools developed their conditions and became more stunning. Aksoy (2011) defined this process as commercialization, or privatization of education.

As these summarized findings have indicated, without examining the country's sociopolitical and economic conditions, Turkish governments supported the involvement of the private sector in education in several ways. For instance, the paid-education model was suggested in the $7^{\text {th }}$ Five Year Development Plan, and the government proposed to reduce the state's responsibility in education by increasing attendance at private schools. Although the privatization of education is not a new suggestion, it is possible to say that this idea spread out the inequality among the students. For many scholars, the main reason behind this transformation was the change in the idea of public services, in which NPM has been the key mechanism in political reform and cultural recreation. 
In Turkey, NPM doctrines have been spread into the public services by the PMBLD (Keskin, 2003). Since both the PMBLD and NPM are compatible with each other in the transformation of education services, and PMBLD recommends several reforms for education services, by combining these reforms with the Five Year Development Plans. For instance, the 8th Five Year Development Plan was emphasizing the importance of NPM for Turkish Public Services, and therefore, the government aimed to transform education services. Moreover, decreasing the role of central government and giving some space to the private sector and nongovernmental organizations in the education sector, were the other results of the implementation of NPM in public services. The abovementioned neoliberal transformations raised the visibility and the involvement of the social movements, or non-governmental organizations, in public administration. For instance, although during the single party period Kemalist modernist policies cleansed the public sphere from the anti-secular or religious discourses, in the multiparty era there are some contradictory attempts from the ISMs, which are seeking more liberal and pluralistic settings. In Turkey during the last four decades, they were struggling with the secular state in order to rescue the free marginal religious voices by using the media and press.

Education is one of the areas that these movements can be seen in action. By producing private education, which is an alternative to public education, the ISMs played a vital role in the creation of social capital in Turkey. For example, while the Kemalist secularist education system and ideology considered education as not only an important means for economic and cultural advancement, but also an integral part of modernity, the ISMs challenges this, and work towards building a pious perspective on education, all the while using the institutional and conceptual ground constructed by Kemalist reforms.

In brief, by using the newly emerged liberal, socio-political, and economic environment, these movements mobilized and globalized themselves and their practices. This chapter has indicated that rather than taking into account non-rational or non-positivist policy interventions, the implementation of the NPM and PMBLD doctrines created opportunity spaces. These spaces allowed new possibilities for Islamic actors to have their own voice and institutional networks in the public sphere. The ISMs, which are the outcome of the transformed Turkish social structure, described by Gole (2000) as one of the modern new social movements, such as civil rights and labour movements, are involved in a rational game, to carve out space and seek recognition vis-à-vis the state (Yavuz, 2003, p.25). Therefore, in order to understand both why the Islamic social movements are not non-rational or non-positivist policy interventions, their roles in both political and social life is necessary to see that they are not reactionary opposes to modernity, but rather they are challenging some aspects of modernism (Yavuz, 2008, p.39).

\section{References}

Aksoy, N., (2011), 'Türkiye Kamu Eğitiminde Gizli Ticarileşme: Kurumsal Sosyal Sorumluluğun İşleyiş Biçimleri Ve Eğitimi Ticarileştirme İşlevleri', Eğitim Bilim Toplum, Issue: 9 , No: 35

Aktay, Y., (1997), Body, Text, Identity: The Islamist Discourse Of Authenticity In Modern Turkey, Unpublished Ph.D. Dissertation, The Middle East Technical University

Apple, W.M., (2006), Educating The 'Right' Way: Markets, Standards, God, And Inequality, 2nd Ed., New York: Routledge, 2006.

Ball, S.J. \& Youdell, D., (2007), 'Hidden Privatization In Public Education', Education International 5th World Congress Preliminary Report, July, London: Institute Of Education, University Of London, [Electronic], [Accessed On: 25 Nov 2011], Available From: 
Http://Pages.Eiie.Org/Quadrennialreport/2007/Upload/Content_Trsl_Images/630/Hidd en_Privatisation- En.Pdf

Bary, J., Berg, E., And Chandler J., (2006), 'Movement And Change In The Public Sector: Bringing Social Movements Into The Analysis', Public Management Review, Vol: 8, Issue: 3, Pp: 433-448, [Accessed: $26^{\text {th }}$ January 2012], Available From:

Http://Www.Informaworld.Com/Openurl?Genre=Article \&Doi=10.1080/14719030600 853329\&Magic $=$ Cr Ossref

Beriş, Y. And Dicle, E. (2004) "Reforming Public Management And Managing Reform In Turkey," In Turkey In Focus, Issue: 4, Tusiad: Washington Office.

Beriş, H. E., (2008), 'Türkiye'de 1980 Sonrası Devlet Sermaye İlişkileri Ve „Parçalı Burjuvazinin Oluşumu', (The State-Capital Relation After 1980 And The Formation Of Partial Bourgeoisie In Turkey), Ekonomik Yaklaşım, Vol: 19, No: 69, 33-45

Bevir, M. And Rhodes, R. A. W., (2003), 'Searching For Civil Society: Changing Patterns Of Governance In Britain', Public Administration, Vol: 81, No: 1, Pp: 41 - 62.

Boratav, K., (1995), 'Ekonomi Ve Küreselleşme,' In Isin Kansu (Eds), Küreselleşme Hikayesi, Dost Yayınları,

Cohen, J., And Arato, A., (1995), Civil Society And Political Theory, The Mit Press, Cambridge, Massachusetts And London, 3rd Ed.

Della Porta, D., \& Diani, M., (1999), Social Movements: An Introduction, Oxford: Blackwell

Dpt, (2000), 8. Beş Yıllık Kalkınma Planı, 2001-2005, İnsan Kaynaklarının Geliştirilmesi: Eğitim, [Accessed On: 10/04/2013], Available From: Http://Www.Ekutup.Dpt.Gov.Tr/Kalkinmaplanlari

Ferlie, E., [Et. Al], (1996), The New Public Management In Action, Oxford, Oxford University Press

Gellner, E., (1994), Conditions Of Liberty: Civil Society And Its Rivals, Newyork: Penguin Press.

Gök, F., (2003), 'Eğitimin Özelleştirilmesi' Neoliberalizmin Tahribatı : Türkiye'de Ekonomi, Toplum Ve Cinsiyet, Der: Balkan, N., Savran, S., Istanbul: Metis Yayınlari

Gole, N., (2000), 'Snapshots Of Islamic Modernities', Daedalus, Vol: 129, No: 1, Pp: 91-117

Hood, C., (1991), 'A Public Management For All Seasons?', Public Administration, Vol: 69, No:1, Pp3-19

Hood, C., (1995), 'The 'New Public Management' In The 1980s: Variations On A Theme?' Accounting, Organizations And Society, Vol; 20, No:2/3, Pp:93-109

Keskin, N., (2003), Eğitimde Reform Kamu Yönetimi I. Ulusal Kurultayı (18-19 Aral I K 2003). İnönü Üniversitesi, Malatya.

Melluci, A., (1996), Challenging Codes: Collective Action In The Information Age, Cambridge University Press: Cambridge

Munyar, V., (9 $9^{\text {th }}$ April, 2012), 'Ilköğretim Öğrencisi İçin 1500 Lira Özel Okul Desteği Versek Devlete Yükü Azalır', Hurriyet, Http://Www.Hurriyet.Com.Tr/Yazarlar/20302572.Asp

Murphy, J., (1996), The Privatization Of Schooling: Problems And Possibilities, Corwin Press, Inc. Usa

Newman, J. (2001), Modernising Governance: New Labour, Policy And Society, London: Sage.

Oecd, (2010), 'Value For Money In Government: Public Administration After 'New Public Management', Available From:

Http://Www.Planejamento.Gov.Br/Secretarias/Upload/Arquivos/Seges/Arquivos/Ocde 2011/Oecd_Publ Ic_Management.Pdf 
Özdalga, E., (1999), Education In The Name Of 'Order And Progress' Reflections On The Recent Eight Year Obligatory School Reform In Turkey. The Muslim World, Vol:89, Pp: 414-438. Doi: 10.1111/J.1478-1913.1999.Tb02756.X

Sayılan, F., (2007), Kresellesme Ve Egitimdeki Degisim, (Editor: Ebru Oguz, Ayfer Yakar). Kuresellesme Ve Egitim, (59-81), Ankara, Dipnot Yayinlari

Serim, B., (17th April, 2012), Http://Www.Odatv.Com/N.Php?N=CemaatOkullarina-Devlet-Destegi- 1704121200

Şimşek, S., (2004), 'New Social Movements In Turkey Since 1980', Turkish Studies, Vol.5, No.2, Summer , [Online] [Accessed: 30th January 2012], Available From: Doi: 10.1080/1468384042000228611

Sozen, S. Ve I. Shaw, (2002), 'The International Applicability Of 'New' Public Management: Lessons From Turkey', The International Journal Of Public Sector Management. Vol. 15 No. 6, S. 475- 486, 2002

Tesev (2001), From Point Of The Households The Reasons And The Proposals For Prevention Of Corruption In Turkey, Istanbul, Turkish

Tolofari, S., (2005), New Public Management And Education, Policy Futures In Education, Vol: 3, No: 1, Pp:75-89, Available From: Http://Dx.Doi.Org/10.2304/Pfie.2005.3.1.11 [Accessed: 30th November 2011]

Turam, B., (2004), 'The Politics Of Engagement Between Islam And The State: Ambivalences Of Civil Society' British Journal Of Sociology, Vol: 55, No: 2, Reprinted In Shahram Akbarzadeh (Ed) 2006. Islam And Globalization. Routledge

Turam, B., (2007), Between Islam And The State: The Politics Of Engagement, Stanford, California: Stanford University Press.

Turam, B., (2011), Turkiye'de Islam Ve Devlet: Demokrasi, Etkilesim, Donusum, Istanbul: Bilgi Universitesi Yayinlari

Uysal, A. (Ed.), (2009), Siyasal İslam Ve Liberalizm: Endonezya, İran, Mısır, Tunus, Türkiye, İzmir Yakın Kitabevi

Wiktorowicz, Q., (2004), Islamic Activism: A Social Movement Theory Approach. Bloomington: Indiana University Press.

Yaşamış, F. D. (2003). State Reform İn Turkey: Reasons, Needs And Strategies. Australian Journal Of Public Administration, 62(4), 93-107.

Yavuz, H., (2000), 'Cleansing Islam From The Public Sphere', Journal Of International Affairs, Fall 2000, 54, No:1

Yavuz, H., (2003), Islamic Political Identity In Turkey, Oxford University Press, New York

Yavuz, H., (2008), Modernlesen Muslumanlar: Nurcular, Naksiler, Milli Gorus Ve Ak Parti (Islamic Political Identity In Turkey), Kitap Yayinevi, Istanbul.

Yıldırım, H.A., (2002), Eğitimde Toplam Kalite Yönetimi, Nobel Yayınevi, Ankara. 